\title{
Effect of Oxytocin on uterine involution, cervical dilation and resumption of ovarian activity post- lambing in Ossimi ewes
}

\author{
M.Y. Mohamed ${ }^{1 *}$, A.A. Abd El-Hakeam², O.M. Abd El-Salam ${ }^{1}$ \\ ${ }^{1}$ Animal Production Research Institute (APRI), Agricultural Research center (ARC), NC 12618, Dokki, Giza, \\ ${ }^{2}$ Department of Animal Production, Faculty of Agriculture, Minia University, Egypt. \\ *Corresponding author:dr_yassin2005@yahoo.com
}

Journal of Livestock Scienc (ISSN online 2277-6214) 12:161-169

Received on 22 2//21, Accepted on 24/4/21, Published on 1/5/21

doi.10.33259/JLivestSci.2021.161-169

\begin{abstract}
Anatomy and cervix structure in the ewes commonly inhibit non-surgical artificial insemination (AI) and embryo transfer (ET), thus limiting their commercial use in sheep. This research was carried out to determine whether oxytocin (OT) dilates the cervix and promotes uterine activity. Animals $(\mathrm{n}=24)$ were assigned to three groups (8 each). The first and second groups (G1 \& G2) were intramuscularly (IM) and intravenously (IV) weekly injected with 20 IU of OT, respectively. However, the third group was IM injected with saline (control, G3). Results showed that the restoration of vaginal length had a similar interval in all groups. The deepest penetration distance of the cervix was greater in OT-treated than in control ewes. OT injection positively affected $(P<0.001)$ the frequency of successful uterine entries. There were significant $(P<0.05)$ increases in follicles number and diameter in OT-treated groups compared to control. Also, the results indicated earlier uterine horn symmetry in OT-treated groups than in control, which may suggest beneficial effects of OT on earlier uterine involution through $1^{\text {st }}$ month post-lambing. Treated ewes showed higher estrus rate $(100 \& 100 \mathrm{vs}$ $75 \%$ ) and conception rate $(87.5 \& 87.5$ vs $62.50 \%)$, lower No. of service per conception ( $1.38 \& 1.25$ vs 1.63 serv.), and shorter at $1^{\text {st }}$ estrus post-lambing ( $57.63 \& 55.75$ vs $71.38 \mathrm{~d}$ ) than in control. Milk yield was not significantly affected by treatment. Method of OT-injection (IV or IM) had no significant effect on most reproductive parameters, although the IV method was more potent and effective than IM. In conclusion, postlambing OT injection would lead to earlier uterine innovation, activate ovarian functions, and dilate and penetrate the cervical canal and subsequently improve the reproductive traits of Ossimi ewes. Also, OT injection could be useful to improve the procedures of AI and ET in sheep.
\end{abstract}

Key word: Cervix; ovary; uterine; Oxytocin; sheep 


\section{Introduction}

The easiest and simplest technique for ewes artificial insemination (AI) and embryo transfer (ET) are transcervical AI and ET (Wulster-Radcliffe and Lewis, 2002) while the anatomical structure of the cervix in ewes usually inhibit intrauterine AI and transcervical ET from being used commercially in ewes (Anel et al., 2006; Candappa et al., 2009; Lewis, 2010).

Capable transcervical AI, embryo collection, and ET procedures for sheep may eliminate the need for surgical procedures. Sheep-specific transcervical procedures have been reported, but pregnancy rates after the procedures have been disappointing (Wulster-Radcliffe et al., 2004; Anel et al., 2006). Some of the procedures had included treatments to dilate the cervix and reduce the difficulty of manipulating a catheter through the cervix and into the uterus (Wulster-Radcliffe et al., 2004; Anel et al., 2006; Candappa et al., 2009). Several investigations have shown that the peptide hormone (OT) can elevate cervical dilation (Flohr et al., 1999; Lewis, 2010; Masoudi et al., 2012). So, if we can raise the percentage of cervical penetration with OT-injection in ewes, nonsurgical AI and ET would be a reasonable way to do that.

For many years attempts have been made to observe the rate of uterine involution by administering exogenous drugs. Most of the studies have been conducted using exogenous hormones in the ewe (Tian and Noakes, 1991).In order to increase uterine contractility and, consequently, acceleration of uterine involution during the puerperal phase, treatment protocols using uterotonic drugs or hormones are applied. Practices during the post-partum period included natural prostaglandin or its synthetic analogues and oxytocin (Abdel-Khalek et al., 2012, 2013). Oxytocin treatment was the most practical and efficacious method for prolonging corpus luteum (CL) functions and improvingewes' reproductive performance(Abdel-Khalek et al., 2015; Vanderwall et al., 2016; Mohamed and Abd El-Hakeam, 2017). OT preparations can be used as a single treatment or as repeated applications to induce and increase uterotonic activity during the cows' early puerperal phase. They are mainly administered as intramuscular injections, but intravenous, subcutaneous, epidural, and intravaginal treatment forms have also been reported (Sobiraj et al., 1998; Starke et al., 1998). Abdel-Khalek et al. (2015) reported that OT injection within $12 \mathrm{~h}$ post-calving produced early uterine involution and had a marked effect in positive trends on the reproductive performance of Friesian cows.

Thus, this experiment was conducted to examine the effect of exogenous oxytocin (IV / IM) on cervical penetration, stimulation of uterine activity, and improved reproductive performance of Ossimi ewes.

\section{Materials and methods}

The current study was conducted at Fac. of Agri. Exp. Station, Minia Univ., in partnership with the Animal Production Research Institute (APRI), Agricultural Research Centre (ARC), Ministry of Agriculture, Egypt. Experimental design

This investigation was conducted post-lambing on 24 adult Ossimi ewes having 40-45 $\mathrm{kg}$ body weight (BW). All experimental ewes had normal lambing with placental expulsion duration from 5 to $15 \mathrm{~h}$, and no reproductive obstacles emerged post-lambing. Animals $(n=24)$ were assigned to three equal groups $(8$ each), according to their BW and reproductive status. In the $1^{\text {st }}(\mathrm{G} 1)$ and $2^{\text {nd }}(\mathrm{G} 2)$ groups, animals at $\mathrm{d} 7$ post-lambing were intramuscularly (IM) and intravenously (IV) weekly injected for four weeks with 20 IU of oxytocin (OT) (Adwia Co., Egypt), respectively. The 3rd (G3) group animals were IM injected with saline solution $(0.9 \%$ $\mathrm{NaCl}$ ) and considered the control group.

Management systems

All animals were retained and maintained in similar environmental conditions in a semi-open shaded yard during the experimental period and were fed on a diet that met the requirements of maintenance and production (NRC, 1985). Ewes were fed group feeding on a total mixed ration consisted of $60 \%$ concentrate mixture, $20 \%$ clover hay, and $20 \%$ rice straw. Fresh water and minerals were accessible at all times of the experiment.

\section{Experimental procedures}

To measure cervical penetration $(\mathrm{CP})$ distance and vaginal length, ewes were examined and measured pre- and 20 min post-OT injection using a stainless steel catheter of bovine artificial insemination (BAI) with 4 $\mathrm{mm}$ diameter and $40 \mathrm{~cm}$ length. The ovine speculum was utilized to open the ewe's vagina, and the catheter was inserted to arrive at the cervix. Pre-OT injection, the catheter penetration chance through the cervix was low but increased post-OT injection. The difference in penetration distance $(\mathrm{cm})$ between pre- and post- OT injection was considered CP distance (Masoudi et al., 2012).

Ovarian activity and changes in uterine horns diameters (gravid and non-gravid) were monitored using ultrasound examination by transportable sonar (model HVat-030609F413) with $8 \mathrm{MHz}$ probe. Measurements were recorded on days $10,15,20,25$, and 30 post-lambing by counting the various follicles types existent with different size stage, and the number and diameter of CL were also recorded. Uterine involution (UI) was viewed 
as complete when both gravid and non-gravid horns were almost in even measure. No further change in breadth of horns or cervix occurred between two sequential assessments (Abdel-Khalek et al., 2015).

The estrus activity for all ewes was monitored twice daily by using a teaser ram. The ram was exchanged between tested ewes. The ewe was considered in estrus when standing for mounting and receptive to the ram. The service day was recorded and then followed up to 17 days after that for estrus' return. Non-return ewes were ultrasound checked 30 days after first mating to diagnose pregnancy, and in any questionable case, the examination was performed again after 15 days later.

Conceived ewes were counted to determine the conception rate through 60 days post-mating. Besides, post-lambing intervals of sexual activity were calculated: from lambing to 1st estrus, 1st service and conception plus the number of services/conception (NSC) and service period. The conception rate, lambing rate, and twinning rate were determined. Fecundity was calculated (number of lambs born / total number of ewes treated) $\mathrm{x}$ 100. Experimental ewes were hand milked twice daily every week by milking one teat, while the lamb suckles another teat to stimulate and estimate daily and total milk yield.

Blood sampling and hormonal assay

At ten days post-lambing, individual blood samples were collected via the jugular vein from all ewes every five days for one cycle in the morning before feeding using $10 \mathrm{ml}$ un-coagulated tubes. Serum was separated by centrifugation of blood at $1,800 \times g$ for $20 \mathrm{~min}$ and then stored at $-20{ }^{\circ} \mathrm{C}$ until used later to assay progesterone levels $\left(\mathrm{P}_{4}\right)$ and estradiol $\left(\mathrm{E}_{2}\right)$. Quantitative determination of $\mathrm{P}_{4}$ and $\mathrm{E}_{2}$ was carried out using radioimmunoassay kits DSL-USA. Catalog No.3900 (Meizger, 1992).

Statistical analysis

Data were statistically analyzed using the GLM procedure by SAS statistical analysis program. Duncan's Multiple-rang test recorded the differences among means. The model used was: $Y_{i j}=\mu+G_{i}+e_{i j}$ Where:

$\mathrm{Y}_{\mathrm{ij}}=$ an observation, $\mu=$ overall means, $\mathrm{G}_{\mathrm{i}}=$ effect of treatment ( $\mathrm{i}=$ control G3, Oxytocin inj. G1 \& G2) and eij $=$ random error. Uterine entered rate, the Chi-square test analyzed conception rate, lambing rate and twining rate data.

\section{Results}

In the present experiment, injection of ewes with 20 IU of OT weekly after seven days post-lambing increased $(P<0.001)$ deepest CP (depth before vs. depth after injection; Table 1). Resumption of vaginal length had a similar interval in all experimental groups. Deepest CP was higher in oxytocin-treated than in control ewes. Injection of OT positively affected $(P<0.001)$ the frequency of successful uterine entries (Table 1). The catheter was passed into the uterus in 62.5 and $75 \%$ of the oxytocin-treated ewes (G1 and G2, respectively). The catheter could not be passed into the uterus in $87.5 \%$ of the control ewes. There was no difference $(P>0.05)$ between IV and IM injection, though IV injection had a higher CP percentage.

Table (2) showed ovarian activity through $1^{\text {st }}$ month post-lambing for experimental animals. There were significant $(P<0.05)$ increasein average total follicles number $(3.75 \& 3.88$ vs 2.63) and dominant follicle diameter $(6.61 \& 6.76$ vs $6.18 \mathrm{~mm})$ in OT treated ewes compared to control. However, number and diameter of $\mathrm{CL}$ were greater $(P>0.05)$ among experimental groups as follow $1.00 \& 1.28$ vs 0.71 and $7.40 \& 7.63$ vs 7.18 , for G1, G2 and G3, respectively. Also, the injection methods (IM or IV) did not differ in their influence on ovarian activity, although the IV method was more potent than IM.

Data in Table (3) showed that diameter of non-gravid $(\mathrm{NGH})$ and gravid $(\mathrm{GH})$ horns of the uterus showed highly significant $(P<0.001)$ differences among the experimental groups at 10,15 , and 20 days postlambing, but it slightly declined by progressing in post-lambing days for all experimental groups but at various rates in each group. However, insignificant $(P>0.05)$ differences were found at 25 and 30 days post-lambing in diameter among the experimental groups. Through post-lambing days, NGH and GH diameters were significantly $(P<0.001)$ wider in G3 (control) than in OT treated groups (G2 \& G3). Results in Table (3) indicated that post-lambing intervals needed for $\mathrm{NGH}$ and $\mathrm{GH}$ symmetry and cervical closure were significantly decreased $(P<0.001)$ by OT injection, ranging 7.5 and $10.5-11.5$ days, respectively.

Serum progesterone $\left(\mathrm{P}_{4}\right)$ and estradiol $\left(\mathrm{E}_{2}\right)$ levels through the $1^{\text {st }}$ month post-lambing of OT-treated ewes between $\mathrm{d} 10$ and $\mathrm{d} 30$ are shown in Table (4). $\mathrm{P}_{4}$ level at day ten post-lambing was so low ranged between 0.648 $0.773 \mathrm{ng} / \mathrm{ml}$, less than $1 \mathrm{ng} / \mathrm{ml}$ in all ewes, which indicated that the ewes were in post-lambing anestrous status and CL regression stage. There was a significant $(P<0.001)$ increase in the overall mean of $\mathrm{P}_{4}$ in OT-groups compared to saline-group, meaning the presence and appearance of some functional CL in some ewes. Meanwhile, its levels increased and passed more than $1 \mathrm{ng} / \mathrm{ml}(>4 \mathrm{ng} / \mathrm{ml})$ in all groups between days 20 and 25 post-lambing, indicating returning of ovarian activity. At the same time, estradiol levels were taken the opposite direction in all groups since they significantly $(P<0.001)$ increased to over $33 \mathrm{pg} / \mathrm{ml}$ at 10 and 30 days postlambing (Table, 4). Also, OT-treated ewes had significantly higher levels of estradiol compared to saline-treated ewes (control). 
Table 1.The penetration distance $(\mathrm{cm})$ into the cervix of oxytocin treated ewes post-lambing.

\begin{tabular}{|c|c|c|c|c|c|}
\hline \multirow{2}{*}{ Parameters } & \multicolumn{3}{|c|}{ Experimental groups } & \multirow{2}{*}{ ASE } & \multirow{2}{*}{ P. value } \\
\cline { 2 - 4 } & $\mathrm{G} 1$ & $\mathrm{G} 2$ & $\mathrm{G} 3$ & \\
\hline Cervical penetration $(\mathrm{cm})$ & \multicolumn{5}{|c|}{} \\
\hline Before OT inj. & 1.786 & 1.929 & 1.843 & 0.054 & 0.2015 \\
\hline After OT inj. & $3.814^{\mathrm{a}}$ & $3.858^{\mathrm{a}}$ & $1.886^{\mathrm{b}}$ & 0.118 & 0.0001 \\
\hline Vaginal length & 3.829 & 3.700 & 3.800 & 0.129 & 0.7640 \\
\hline Uterine entered / no. of ewe (\%) & $62.50(5 / 8)$ & $75.00(6 / 8)$ & $12.50(1 / 8)$ & & 0.0046 \\
\hline
\end{tabular}

$a$ and $b$ Means within the same row followed by different superscripts are significantly different $(P<0.05)$. G1= IMOT inj., G2=IVOT inj., $\mathrm{G} 3=$ control, $\mathrm{OT}=$ oxytocin.

Table 2. Ovarian activity within the 1st month post-lambing of oxytocin treated ewes.

\begin{tabular}{|l|c|c|c|c|c|}
\hline \multirow{2}{*}{ Ovarian parameters } & \multicolumn{3}{|c|}{ Experimental groups } & \multirow{2}{*}{ \pm SE } & \multirow{2}{*}{ P. value } \\
\cline { 2 - 4 } & $\mathrm{G} 1$ & $\mathrm{G} 2$ & $\mathrm{G} 3$ & & \\
\hline Ewes monitored, $\mathrm{n}$ & 8 & 8 & 8 & & \\
\hline Ovarian follicles: & & & & & \\
\hline Small $(\leq 3 \mathrm{~mm})$ & 1.250 & 1.125 & 0.750 & 0.242 & 0.3352 \\
\hline Medium $(>3<5 \mathrm{~mm})$ & 1.125 & 1.250 & 0.750 & 0.242 & 0.3352 \\
\hline Large $(\geq 5 \mathrm{~mm})$ & 1.375 & 1.500 & 1.125 & 0.275 & 0.6252 \\
\hline Total follicles, $\mathrm{n}$ & $3.750^{\mathrm{a}}$ & $3.875^{\mathrm{a}}$ & $2.625^{\mathrm{b}}$ & 0.291 & 0.0113 \\
\hline Dominant follicle diameter, $\mathrm{mm}$ & $6.613^{\mathrm{a}}$ & $6.763^{\mathrm{a}}$ & $6.175^{\mathrm{b}}$ & 0.165 & 0.0420 \\
\hline Corpus luteum, $\mathrm{n}$ & 1.000 & 1.288 & 0.713 & 0.254 & 0.2991 \\
\hline Corpus luteum diameter, mm & 7.400 & 7.625 & 7.188 & 0.206 & 0.3433 \\
\hline
\end{tabular}

$\mathrm{a}$ and $\mathrm{b}$ Means within the same row followed by different superscripts are significantly different $(P<0.05)$. G1= IMOT inj., G2=IVOT inj., G3= control.

Table 3. Changes in diameter $(\mathrm{cm})$ of gravid and non-gravid uterine horns and uterine involution within the 1 st month post-lambing of oxytocin treated ewes.

\begin{tabular}{|c|c|c|c|c|c|}
\hline \multirow{2}{*}{$\begin{array}{l}\text { Days } \\
\text { lambing }\end{array}$} & \multicolumn{3}{|c|}{ Experimental groups } & \multirow{2}{*}{$\pm \mathrm{SE}$} & \multirow{2}{*}{ P. value } \\
\hline & G1 & G2 & G3 & & \\
\hline \multicolumn{6}{|c|}{ Uterine horn (non-gravid) diameter $(\mathrm{cm})$} \\
\hline 10 & $1.929^{b}$ & $2.043^{b}$ & $3.071^{\mathrm{a}}$ & 0.056 & 0.0001 \\
\hline 15 & $1.814^{\mathrm{b}}$ & $1.843^{\mathrm{b}}$ & $2.158^{\mathrm{a}}$ & 0.068 & 0.0029 \\
\hline 20 & $1.429^{\mathrm{b}}$ & $1.358^{\mathrm{b}}$ & $1.658^{\mathrm{a}}$ & 0.054 & 0.0020 \\
\hline 25 & 1.310 & 1.253 & 1.418 & 0.060 & 0.1706 \\
\hline 30 & 1.230 & 1.214 & 1.344 & 0.055 & 0.2100 \\
\hline Overall means & $1.543^{b}$ & $1.541^{\mathrm{b}}$ & $1.929^{\mathrm{a}}$ & 0.026 & $<0.0001$ \\
\hline \multicolumn{6}{|c|}{ Uterine horn (gravid) diameter (cm) } \\
\hline 10 & $4.029^{b}$ & $4.143^{b}$ & $5.172^{\mathrm{a}}$ & 0.056 & 0.0001 \\
\hline 15 & $3.914^{\mathrm{b}}$ & $3.943^{\mathrm{b}}$ & $4.258^{\mathrm{a}}$ & 0.068 & 0.0029 \\
\hline 20 & $3.529^{b}$ & $3.458^{\mathrm{b}}$ & $3.758^{\mathrm{a}}$ & 0.054 & 0.0020 \\
\hline 25 & 3.410 & 3.353 & 3.518 & 0.060 & 0.1706 \\
\hline 30 & 3.330 & 3.314 & 3.444 & 0.055 & 0.2100 \\
\hline Overall means & $3.642^{b}$ & $3.641^{\mathrm{b}}$ & $4.029^{\mathrm{a}}$ & 0.026 & 0.0001 \\
\hline \multicolumn{6}{|c|}{ Uterine involution parameters (day) } \\
\hline Symmetric horns & $22.858^{\mathrm{b}}$ & $22.714^{b}$ & $30.286^{\mathrm{a}}$ & 0.689 & 0.0001 \\
\hline Cervical closure & $24.429^{b}$ & $23.286^{\mathrm{b}}$ & $34.858^{\mathrm{a}}$ & 0.707 & 0.0001 \\
\hline
\end{tabular}

$\mathrm{a}$ and $\mathrm{b}$ Means within the same row followed by different superscripts are significantly different $(P<0.05)$. G1= IMOT inj., G2=IVOT inj., $\mathrm{G} 3=$ control.

Reproductive traits of OT-treated ewes post-lambing are presented in Table (5). Results indicated that estrus duration (ED), $1^{\text {st }}$ estrus post-lambing (FEPL) and $1^{\text {st }}$ service post-lambing (FSPL) were significantly enhanced $(P<0.05)$ by OT injection. However, there were slight $(P>0.05)$ percent of increases for OT-treated ewes (G1 \& G2) in the rates of some parameters such as estrus rate $(33.33 \& 33.3 \%)$, NSC (23.08 \& $15.38 \%)$, lambing rate $(40 \& 40 \%)$, litter size $(19.08 \& 7.17 \%)$, and fecundity $(66.67 \& 50 \%)$ for G2 and G1, respectively vs control group (G3).

Milk yield (total, TMY \& daily, DMY) is presented in Table (5) and Figure (1). Data showed that TMY and DMY were not significantly differed $(P>0.05)$ among groups, despite there was a propensity decrease in TMY and DMY from OT-treated ewes (G2 \& G3) vs. control (G1). 
Table 4. Progesterone and estradiol levels within the 1st month post-lambing of oxytocin treated ewes.

\begin{tabular}{|c|c|c|c|c|c|}
\hline \multirow{2}{*}{ Days post-lambing } & \multicolumn{3}{|c|}{ Experimental groups } & \multirow{2}{*}{$\pm \mathrm{SE}$} & \multirow{2}{*}{ P. value } \\
\hline & G1 & G2 & G3 & & \\
\hline \multicolumn{6}{|c|}{ Progesterone $\left(\mathrm{P}_{4}, \mathrm{ng} / \mathrm{ml}\right)$} \\
\hline 10 & $0.743^{\mathrm{a}}$ & $0.773^{\mathrm{a}}$ & $0.648^{\mathrm{b}}$ & 0.018 & 0.0020 \\
\hline 15 & $0.828^{\mathrm{a}}$ & $0.870^{\mathrm{a}}$ & $0.723^{\mathrm{b}}$ & 0.019 & 0.0009 \\
\hline 20 & $4.043^{\mathrm{a}}$ & $4.090^{\mathrm{a}}$ & $3.838^{\mathrm{b}}$ & 0.042 & 0.0051 \\
\hline 25 & $4.223^{\mathrm{a}}$ & $4.268^{\mathrm{a}}$ & $4.030^{\mathrm{b}}$ & 0.043 & 0.0082 \\
\hline 30 & $0.803^{\mathrm{b}}$ & $0.858^{\mathrm{a}}$ & $0.678^{\mathrm{c}}$ & 0.011 & 0.0001 \\
\hline Overall means & $2.128^{b}$ & $2.172^{\mathrm{a}}$ & $1.983^{\mathrm{c}}$ & 0.013 & 0.0001 \\
\hline \multicolumn{6}{|l|}{ Estradiol $\left(\mathrm{E}_{2}, \mathrm{Pg} / \mathrm{ml}\right)$} \\
\hline 10 & $36.183^{\mathrm{a}}$ & $36.900^{\mathrm{a}}$ & $33.850^{\mathrm{b}}$ & 0.298 & 0.0001 \\
\hline 15 & $4.490^{\mathrm{a}}$ & $4.570^{\mathrm{a}}$ & $4.393^{\mathrm{a}}$ & 0.155 & 0.7279 \\
\hline 20 & $2.880^{\mathrm{ab}}$ & $2.980^{\mathrm{a}}$ & $2.670^{\mathrm{b}}$ & 0.066 & 0.0249 \\
\hline 25 & $3.160^{\mathrm{b}}$ & $3.293^{\mathrm{a}}$ & $3.040^{\mathrm{c}}$ & 0.029 & 0.0007 \\
\hline 30 & $34.988^{\mathrm{a}}$ & $35.208^{\mathrm{a}}$ & $33.980^{\mathrm{b}}$ & 0.187 & 0.0027 \\
\hline Overall means & $16.340^{\mathrm{b}}$ & $16.590^{a}$ & $15.587^{\mathrm{c}}$ & 0.078 & 0.0001 \\
\hline
\end{tabular}

$\mathrm{a}$ and $\mathrm{b}$ Means within the same row followed by different superscripts are significantly different $(\boldsymbol{P}<0.05)$. G1= IMOT inj., G2=IVOTinj., G3= control.

Table 5. Reproductive performance and milk yield of oxytocin treated ewes post-lambing.

\begin{tabular}{|c|c|c|c|c|c|}
\hline \multirow{2}{*}{ Days post-lambing } & \multicolumn{3}{|c|}{ Experimental groups } & \multirow{2}{*}{$\pm \mathrm{SE}$} & \multirow{2}{*}{ P. value } \\
\hline & G1 & $\mathrm{G} 2$ & G3 & & \\
\hline \multicolumn{6}{|c|}{ Reproductive performance } \\
\hline Total ewes, $\mathrm{n}$ & 8 & 8 & 8 & & \\
\hline Ewes in estrus, $\mathrm{n}$ & 8 & 8 & 6 & & \\
\hline Estrus rate, $\%$ & 100 & 100 & 75 & & 0.1182 \\
\hline Estrus duration, $\mathrm{h}$ & $34.25^{\mathrm{b}}$ & $33.75^{b}$ & $37.125^{\mathrm{a}}$ & 0.698 & 0.0053 \\
\hline FEPL, day & $39.75^{b}$ & $38.50^{\mathrm{b}}$ & $59.25^{\mathrm{a}}$ & 1.768 & 0.0001 \\
\hline FSPL, day & $57.625^{b}$ & $55.750^{\mathrm{b}}$ & $71.375^{\mathrm{a}}$ & 1.941 & 0.0001 \\
\hline NSC & 1.375 & 1.250 & 1.625 & 0.177 & 0.3308 \\
\hline Conceived ewes, $\mathrm{n}$ & 7 & 7 & 5 & & \\
\hline Conception rate, $\%$ & 87.50 & 87.50 & 62.50 & & 0.3640 \\
\hline Lambing ewes, $\mathrm{n}$ & 7 & 7 & 5 & & \\
\hline Lambing rate, $\%$ & 87.50 & 87.50 & 62.50 & & 0.3640 \\
\hline Lambs born, $\mathrm{n}$ & 9 & 10 & 6 & & \\
\hline Litter size & 1.286 & 1.429 & 1.200 & 0.188 & 0.7240 \\
\hline Single born, $n$ & 5 & 4 & 4 & & \\
\hline Twins born, $n$ & 2 & 3 & 1 & & \\
\hline Twining rate, $\%$ & 22.22 & 30.00 & 16.67 & & 0.8229 \\
\hline Fecundity, \% & 112.50 & 125.00 & 75.00 & 24.245 & 0.3352 \\
\hline \multicolumn{6}{|l|}{ Milk yield } \\
\hline Total milk yield, kg & 31.262 & 31.573 & 32.652 & 0.894 & 0.6349 \\
\hline daily milk yield, $\mathrm{g}$ & 376.501 & 375.876 & 388.730 & 10.647 & 0.6347 \\
\hline
\end{tabular}

$a$ and $b$ Means within the same row followed by different superscripts are significantly different $(P<0.05)$. G1 $=$ IM OT inj., G2=IV OT inj., G3= control, FEPL $=1^{\text {st }}$ estrus post-lambing, $\mathrm{FSPL}=1^{\text {st }}$ service post-lambing, $\mathrm{NSC}=$ No of service per conception. 


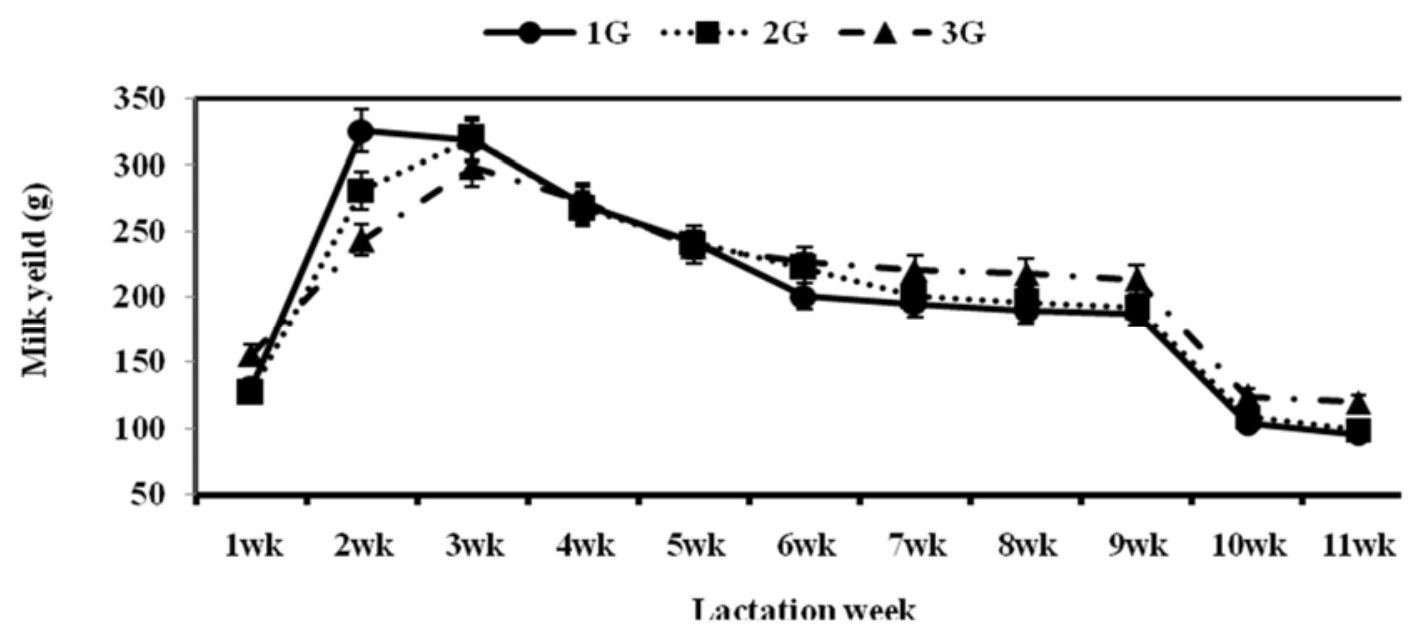

Figure 1. Milk yield post-lambing of oxytocin treated Ossimi ewes. G1= IM OT inj., G2=IV OT inj., G3= control, OT= oxytocin.

\section{Discussion}

In the present study, IM or IV injection of OT resulted in increased penetration of BAI pipette into Ossimi ewes' cervix. It allowed easy passing through the cervix into the uterus. This penetration is defined as the catheter's volumepass to the 2nd and 3rd rings of the cervix (Naqvi et al., 2005). Kershaw et al. (2005) reported that morphological and histological investigations of the cervix had shown that inner cervical rings are the main obstacles to AI catheters. The $2^{\text {nd }}$ and $3^{\text {rd }}$ rings are usually out of line with the $1^{\text {st }}$ ring, then are misdirected from the central cavity, and the AI catheter is rarely penetrated more than $1 \mathrm{~cm}$ in the cervix. After OT injection, the pipette could successfully penetrate through the cervix into the uterus. These results are similar to those reported by Stellflug et al. (2001) and Masoudi et al. (2012). Indeed, manipulation of the cervix and the use of an inflexible catheter through the cervix canal can harm the cervix and release harmful compounds against spermatozoa and embryo and thus reducing fertility (Hawk, 1983) while utilizing OT has no adverse impact on the cervix, oocyte, and sperm (Sayre and Lewis, 1996; Stellflug et al., 2001).

Oxytocin doses used in the current study are likely to be pharmacological, and their impacts on uterine contractions, spermatozoa transport, and fetal survival after transmit have not been estimated. Few doses of OT were utilized to promote uterine contractions and stimulate sperm transportation (Khalifa et al., 1992). OT through an increment of the cyclo-oxygenase- 2 mRNA expression causes prostaglandin $\mathrm{E}_{2}$ release from the cervix throughout the estrus period (Shemesh et al., 1997). Prostaglandin $\mathrm{E}_{2}$ can raise CP by affecting the EP2 and EP4 receptors in the cervix (Kershaw-Young et al., 2009). Then, OT caused CP through the effect on releasing prostaglandin E2. Injection of ewes by 20 IU of OT can lead to CP.Sayre and Lewis (1996) illustrated that the lowest dose for entire cervical dilation was $50 \mathrm{IU}$ of OT that stimulated $60 \%$ of the uterine entry rate; also, 200 USP units of OT induced 100\% uterine entry rate with cervical dilation. King et al. (2004) indicated that $10 \mathrm{IU}$ of OT did not affect or reduce the number of lambing ewes, and the cervix could not dilate due to using a low dosage.

The current results showed an enhancement of ovarian activity through $1^{\text {st }}$ month post-lambing in OTtreated ewes,such as increasing total follicles number (42.9 \& 47.6\%) and CL number (40.3 \& 80.65\%). These findings are in agreement with Mohamed and Abd El-Hakeam (2017), who reported that the average number of different follicles and CL counted and their diameters at day $7^{\text {th }}$ post-mating of Ossimi ewes were greater in OTtreated ewes than saline-treated ewes. Vanderwall et al. (2016) reported that OT injection was the most applied and effective way to prolong the CL function. They showed that one protocol of OT includes injected 60 UI IM of OT once daily from 7 to 14 days post ovulation, resulting in prolonged CL action in $60 \%$ to $70 \%$ of injected mares, and it can be easily reversible by giving a luteolytic dose of prostaglandin to begin the renewal of periodic reproductive activity. This might be due to levels of estradiol secretion (Table 5) and releasing of gonadotrophic hormone by the pituitary gland. The consensus in different studies is that the influences of OT are associated with days in the oestrous period, the presence of uterine tissues, levels or combinations of sex hormones, and GnRH. Additional evidence also indicates a close relationship between the synthesis of OT and prostaglandins. 
Uterine involution was considered almost complete when both gravid and non-gravid horns were nearly in symmetry, and this occurred earlier in OT treated groups compared to control. These variations may propose beneficial impacts of OT treatment on gravid uterine horns' involution during the first 30 days post-lambing. Similar results were obtained on cows by Abdel-Khalek et al. (2013 \& 2015). They reported that variations in diameter between the two horns were significant until the 21st and 28th days of the post parturition period in injected cows by OT and PGF compared to 35 days in the control cows. The current results showed an almost similar impact of OT on alterations in the uterine of gravid horns in ewes. The noticed significant variations in the diameter of gravid horns on day ten post-lambing among tested groups showed morphological alterations in horn diameter before ten days post-lambing. In general, the size of the uterus is a major indicator of uterine involution (Zemjanis, 1970). Aboul-Fadle (2000) reported that the uterus diameter decreased in half on the fifthday post-lambing. Its length decreased in half on the fifteenth-day post-lambing, and the uterus recovers its normal dimension on day 19 to 21 if there is no satisfactory infection.

The interval from lambing to symmetrical uterine horns was significantly shorter in G1 and G2 than in G3. However, cervical closure was completed substantially earlier in G2, followed by in G1 than in G3. Burton et al. (1990) illustrated that the quantitative uterotonic impacts of OT and the administration of prostaglandins within 12 hours after parturition because these hormones depend on the presence and susceptibility of membrane receptors, which are more or less specific for short hours postpartum. This may be related to the availability of proximal membrane receptors for OT and prostaglandin hormones and/or their relationship (Abdel-Khalek et al., 2013\& 2015). IM or IV injection of OT raised similar uterotonic impacts in healthy, early post-lambing ewes. Treatment of OT seems to increase the frequency of uterine muscle contractions (Bajcsy et al., 2006), as it affects directly the uterine muscle and indirectly, by releasing endometrium of PGF2 $\alpha$ (Guay and Lamothe, 1980) that might be reflected on CL regression and decreasing of progesterone secretion that was shown in Table (4) in the current study. This decrease in progesterone will have positive feedback on the hypothalamus to release GnRH and the pituitary to release both FSH firstly for development and maturation of ovarian follicles (Table, 2) and increase of estradiol release (Table, 4), then LH secondly that stimulate ovulation and formation of CL which release and increase progesterone as shown in the present study (Table, 4).

Reproductive traits of Ossimi ewes injected at day seven post-lambing by oxytocin were improved. These results are in agreement with Abdel-Khalek et al. (2013\& 2015) and Mohamed and Abd El-Hakeam (2017). They reported that enhancement in reproductive parameters such as estrus behaviour, fertility rate, lambing rate, litter size, and fecundity of OT-injected ewes. This improvement of reproductive traits may be due to the positive alteration in CP (Table 1), ovarian activity (Table 2), uterine involution (Table 3), and sexual hormones $\left(\mathrm{P}_{4} \& \mathrm{E}_{2}\right.$, Table 4).

In Africa, sheep is kept both for tangible benefits, such as cash income from animal, milk and meat sales and for home consumption, and intangible benefits including savings, an insurance against emergencies, cultural and ceremonial purposes (Mukhongo et al., 2014). Uterine involution plays an essential role in cows' reproductive performance through the post-calving period (Abdel-Khalek et al., 2015). The noticed current enhancement of reproductive performance of Ossimi ewes in G1 and G2 was also explained and reported earlier by Hays and VanDemark (1953). They also suggested a close correlation between oxytocin release and GnRH secretion.

The uterine involution must be completed 22.8 days after parturition is the most limiting agent for ovarian function restoration after calving (Van De Plassch, 1981). The uterus plays an essential role in the return of ovarian function through the post-lambing days and the return of normal periodic activity post-lambing dependent on the uterus return to non-gravid size and function (Schirar and Martinet, 1982). Thus, uterine involution has an essential role in obtaining pregnancy (Abdel-Khalek et al., 2015).

Generally, OT may be useful in different ways. $1^{\text {st }}$, it could positively influence the speed of sperm motility (Watson et al., 1999). 2nd, paracrine action exhibits itself in the stimulation of seminiferous tubules, epididymis, and prostate contractions (Thackare et al., 2006). Otherwise, OT boosted acting on the smooth muscles and early uterine involution (Langendijk et al., 2002). Additionally, IV or IM injection of OT during the oestrous period affects the ability and frequency of movements of the uterine muscles (Langendijk et al., 2003).

Current results indicated that milk production as a total or daily product was not significantly influenced by OT injection, even though there was a slight decrease in total milk production obtained from ewes in the injected groups (G1 \& G2). These results may somewhat show the influence of hormonal treatment on milk yield. Similar results were obtained on cows (Abdel Khalek et al., 2013 \& 2015) and buffalo cows (Abdel Khalek et al., 2012).

Conclusion

In conclusion, IV and IM injection of OT are effective for CP, ovarian activity, and uterine innovation within the 1st-month post-lambing of Ossimi ewes. After cervical dilation and enhancement of ovarian activity,the problem of cervical rings was fixed. We were able to carry out AI and collect embryos via the cervical canal in the ewes. So, oxytocin is an excellent method to simplify the AI and transfer of ET through the 
cervical canal. However, studies are needed to determine whether transcervical ET after OT treatment will produce acceptable lambing rates.

\section{Conflict of Interest}

\section{Ethics statement}

The authors declare that there is no conflict of interest in this study.

All animal procedures performed following the standards set forth guidelines for the care and use of experimental animals by the Animal Ethics Committee of Fac. of Agri., Minia Univ., and APRI, ARC, Egypt. Notably, using a stainless steel catheter of BAI for measured cervical penetration distance and the vaginal length was under good veterinary care. The catheter has been installed by APRI ethical approval to the animals after sterilization and anesthesiato provide all appropriate conditions and remained under intensive veterinary care during the experimental period.

\section{Software and data repository resources}

None of the data was deposited in an official repository.

\section{References}

1) Abdel-Khalek, A. E., Darwish, S. A., and El-Shahawy, T. Y. (2012). Effect of methergin and oxytocin as ecbolic agents on uterine involution and fertility of Egyptian buffalo cows. Journal of Animal and Poultry Production, 3(8), 399-413.

2) Abdel-Khalek, A. E., El-Harairy, M. A., Mehrez, A. F., and Fouad, W. F. M. (2013). Uterine involution and reproductive performance of lactating friesian cows treated with oxytocin and prostaglandin (PGF2 $\alpha$ ) at calving. Journal of Animal and Poultry Production, 4(6), 349-362.

3) Abdel-Khalek, A. E., Hammad, M. E., Gabr, S. A., and El-Morsy, H. I. (2015). Productive and reproductive performances of primiparous friesian cows in relation with uterine involution induced by oxytocin and prostaglandin of administration at calving. Journal of Animal and Poultry Production, 6(3), 149-161.

4) Aboul-Fadle, W. S. (2000). The effect of calving on reproductive performance in dairy farms. Egyptian Soc. Anim. Reprod. Fert. Twelfth Annual Congr. Giza, 16-18.

5) Anel, L., Alvarez, M., Martinez-Pastor, F., Garcia-Macias, V., Anel, E., and De Paz, P. (2006). Improvement strategies in ovine artificial insemination. Reproduction in Domestic Animals, 41, 30-42.

6) Bajcsy, Á. C., Szenci, O., Van Der Weijden, G. C., Doornenbal, A., Maassen, F., Bartyik, J., and Taverne, M. A. (2006). The effect of a single oxytocin or carbetocin treatment on uterine contractility in early postpartum dairy cows. Theriogenology, 65(2), 400-414.

7) Burton, M. J., Dziuk, H. E., Fahning, M. L., and Zemjanis, R. (1990). Effects of oestradiol cypionate on spontaneous and oxytocin-stimulated postpartum myometrial activity in the cow. British Veterinary Journal, 146(4), 309-315.

8) Candappa, I. B., Bainbridge, H. C., Price, N. T., Hourigan, K. R., and Bartlewski, P. M. (2009). A preliminary study on the suitability of Cervidil ${ }^{\circledR}$ to induce cervical dilation for artificial insemination in ewes. Research in veterinary science, 87(2), 204-206.

9) Flohr, S. F., Wulster-Radcliffe, M. C., and Lewis, G. S. (1999). Development of a transcervical oocyte recovery procedure for sheep. Journal of Animal Science, 77(10), 2583-2586.

10) Guay, P., and Lamothe, P. (1980). Metritis Following Parturition: Serum Progesterone and 17ß-Oestradiol Levels. The Significance of the Corpus luteum and the Advisability of using a Luteolytic Agent as a Treatment. The Canadian Veterinary Journal, 21(1), 18-20.

11) Hawk, H. W. (1983). Sperm survival and transport in the female reproductive tract. Journal of Dairy Science, 66(12), 2645-2660.

12) Hays, R. L., and VanDemark, N. L. (1953). Effect of stimulation of the reproductive organs of the cow on the release of an oxytocin-like substance. Endocrinology, 52(6), 634-637.

13) Kershaw, C. M., Khalid, M., McGowan, M. R., Ingram, K., Leethongdee, S., Wax, G., and Scaramuzzi, R. J. (2005). The anatomy of the sheep cervix and its influence on the transcervical passage of an inseminating pipette into the uterine lumen. Theriogenology, 64(5), 1225-1235.

14) Kershaw-Young, C. M., Khalid, M., McGowan, M. R., Pitsillides, A. A., and Scaramuzzi, R. J. (2009). The mRNA expression of prostaglandin E receptors EP2 and EP4 and the changes in glycosaminoglycans in the sheep cervix during the estrous cycle. Theriogenology, 72(2), 251-261.

15) Khalifa, R. M., Sayre, B. L., and Lewis, G. S. (1992). Exogenous oxytocin dilates the cervix in ewes. Journal of Animal Science, 70(1), 38-42.

16) King, M. E., McKelvey, W. A. C., Dingwall, W. S., Matthews, K. P., Gebbie, F. E., Mylne, M. J. A., Stewart, E., and Robinson, J. J. (2004). Lambing rates and litter sizes following intrauterine or cervical insemination of frozen/thawed semen with or without oxytocin administration. Theriogenology, 62(7), 1236-1244. 
17) Langendijk, P., Bouwman, E. G., Soede, N. M., Taverne, M. A. M., and Kemp, B. (2002). Myometrial activity around estrus in sows: spontaneous activity and effects of estrogens, cloprostenol, seminal plasma and clenbuterol. Theriogenology, 57(5), 1563-1577.

18) Langendijk, P., Bouwman, E. G., Schams, D., Soede, N. M., and Kemp, B. (2003). Effects of different sexual stimuli on oxytocin release, uterine activity and receptive behavior in estrous sows. Theriogenology, 59(3-4), 849-861.

19) Lewis, G. S. (2010). Pregnancy rates after ewes were treated with estradiol-17 $\beta$ and oxytocin. Sheep and Goat Research Journal, 25, 21-25.

20) Masoudi, R., Kohram, H., Shahne, A. Z., Davoud, S. D. M. A., and Sharif, A. A. (2012). Effects of exogenous oxytocin on cervical penetration of Iranian ewes. African Journal of Biotechnology, 11(9), 2398-2401.

21) Meizger, D. A. (1992). Sex steroids effects on the endometrium. Infertile Reproduction Med. Clinic. Amer, 3, 163-186.

22) Mohamed, M. Y., and El-Hakeam, A. (2017). Reproductive performance of Ossimi sheep as affected by oxytocin injection during mating season. Egyptian Journal of Sheep and Goats Sciences, 12(1), 1-8.

23) Mukhongo D.M., Mwai O , Tapio M, Muigai A. (2014). Genetic Diversity and Population Structure of the Indigenous Sheep in Kenya Based on Microsatellite Analysis: Implications for their Conservation. Journal of Livestock Science 5:65-78

24) Naqvi, S. M. K., Pandey, G. K., Gautam, K. K., Joshi, A., Geethalakshmi, V., and Mittal, J. P. (2005). Evaluation of gross anatomical features of cervix of tropical sheep using cervical silicone moulds. Animal Reproduction Science, 85(3-4), 337-344.

25) Sayre, B. L., and Lewis, G. S. (1996). Cervical dilation with exogenous oxytocin does not affect sperm movement into the oviducts in ewes. Theriogenology, 45(8), 1523-1533.

26) Schirar, A., and Martinet, J. (1982). Postpartum ovarian activity and its interaction with the uterus in resuming cyclic activity post-partum. Current Topics in Veterinary Medicine and Animal Science.

27) Shemesh, M., Dombrovski, L., Gurevich, M., Shore, L. S., Fuchs, A. R., and Fields, M. J. (1997). Regulation of bovine cervical secretion of prostaglandins and synthesis of cyclooxygenase by oxytocin. Reproduction, fertility and development, 9(5), 525-530.

28) Sobiraj, A., Hermulheim, A., Herfen, K., and Schulz, S. (1998). Einfluss verschiedener uterotonika auf den nachgeburtsabgung bei rindern nach konservativen und operativen geburtshilflichen eingriffen. Tierärztliche Umschau, 53(7), 392-399.

29) Starke, A., Fricke, H. P., and Elze, K. (1998). Ein behandlungsverfahren zur stimulation der uterusinvolution im fruhpuerperium des rindes: mittels cloprostenol und carbetocin. Tierärztliche Umschau, 53(12), 730-739.

30) Stellflug, J. N., Wulster-Radcliffe, M. C., Hensley, E. L., Cowardin, E. A., Seals, R. C., and Lewis, G. S. (2001). Oxytocin-induced cervical dilation and cervical manipulation in sheep: effects on laparoscopic artificial insemination. Journal of Animal Science, 79(3), 568-573.

31) Thackare, H., Nicholson, H. D., and Whittington, K. (2006). Oxytocin- its role in male reproduction and new potential therapeutic uses. Human Reproduction Update, 12(4), 437-448.

32) Tian, W., and Noakes, D. E. (1991). A radiographic method for measuring the effect of exogenous hormone therapy on uterine involution in ewes. The Veterinary Record, 129(21), 463-466.

33) Van De Plassch, M., (1981). Neve vergleichende aspekte der involution und der puerperalen meteritis. Bei state, Huh and Sau, Mh., Vet. Med., 36, 804-807.

34) Vanderwall, D. K., Parkinson, K. C., and Rigas, J. (2016). How to use oxytocin treatment to prolong corpus luteum function for suppressing estrus in mares. Journal of Equine Veterinary Science, 36, 1-4.

35) Watson, E. D., Nikolakopoulos, E., Gilbert, C., and Goode, J. (1999). Oxytocin in the semen and gonads of the stallion. Theriogenology, 51(4), 855-865.

36) Wulster-Radcliffe, M. C., and Lewis, G. S. (2002). Development of a new transcervical artificial insemination method for sheep: effects of a new transcervical artificial insemination catheter and traversing the cervix on semen quality and fertility. Theriogenology, 58(7), 1361-1371.

37) Wulster-Radcliffe, M. C., Wang, S., and Lewis, G. S. (2004). Transcervical artificial insemination in sheep: effects of a new transcervical artificial insemination instrument and traversing the cervix on pregnancy and lambing rates. Theriogenology, 62(6), 990-1002.

38) Zemjanis, R. (1970). Examination of the cow. in: Diagnostic and therapeutic techniques in animal reproduction. 2nd ed. R. Zemjanis, ed. pp 3-87, The Williams and Wilkins Company, Waverly Press, Inc., Baltimore, MD. 